\title{
Existence of Islamic education in the era of society revolution 5.0
}

\author{
Ahmad Afwan Yazid ${ }^{1, *}$ \\ ${ }^{1}$ University of Muhammadiyah Malang, Indonesia \\ *Corresponding author: afwanyazid@gmail.com
}

\section{KEYWORDS \\ Existence \\ Islamic Education \\ Society 5.0 \\ SUBMITTED 14 Dec 2020 \\ REVISED 22 Jan 2021 \\ ACCEPTED 17 Feb 2021}

\begin{abstract}
Islamic education continues to experience development and change as times change. The shifting and changes in education scheme is a phenomenon which currently happening, the human needs and demands of the times are the reasons that those changes occur. As we all know, this era of society 5.0 is making changes to human life, one of which is the education sector. The problem is how to preserve Islamic Education so it could withstand the era of society 5.0. This article aims to analyze the existence of Islamic Education in the era of society revolution 5.0. Through library research and content analysis, this article confirms that Islamic Education should be able to compete in this everchanging time. The steps that must be taken by Islamic Education in the era of society 5.0, as stated by Rhenald Kasali, are disruptive mindset, self-driving and reshape or create. Islamic Education should be able to utilize technological tools to increase the quality of its education. Islamic Education should increase spiritual, moral and intellectual solidity by increasing the quality of human resources rich in science, technology and imtaq. Islamic Education should have a better sense of development, so the current education institution could be the harmonious future laboratory.
\end{abstract}

(c) The Author(s) 2021.

\section{INTRODUCTION}

Education keeps on developing and changing as time goes, and of course, it also applies to Islamic Education. Nowadays, a conversation between students and teachers is a common thing, back then, it was a rare thing (Riyadi, 2018). The interaction between students and teachers is considered as a success in modern theory education process (Astawa, 2016). Whereas traditional theory claims that teachers are the main source of knowledge and also the centre of on-class learning activity (Ifadah \& Utomo, 2019). Teachers as the main source or could also be stated as teacher-centred on modern education context is experiencing a shift on its role, which is being only a facilitator, and the current education is shifting its centre to the students or student-centered (Priatmoko, 2018).

The education scheme encounters a change, and a shift is a phenomenon which currently happening, with human needs and demands of the times being the reason that those changes occur. The era of industrial revolution 4.0 is not over yet, and now the era of society revolution 5.0 is coming with its complex impacts (Umro, 2020). The era of society revolution 5.0 is affecting every human life aspects, and the educational aspect is no exception. This era is marked by centralized technology roles in human life (Priatmoko, 2018). It is no wonder if the term "Education 5.0" occurs in the education sector.

Education 5.0 is a manifestation of the Society 5.0 development which is a leap from Industry 4.0 and according to Jeff Borden, is the accumulation of neuroscience, cogni- tive psychology, and education technology. Society 5.0 is a phenomenon which emerges as a response to the need of five society revolution in which human and machine are synchronized to gain solutions, solve problems, as well as possible, new innovations.

Education 5.0 aims to get rid of the social gap that exists in the society; it differs with industrial era 4.0, which only focuses on business. The era of society 5.0 is designed so that humans met all of their needs -individual as well as many people (Nastiti \& Abdu, 2020).

And how does Islamic Education deal with this? How to preserve Islamic Education so that it survives the era of society revolution 5.0? Based on the research findings, there are some causes that could slow down the development of Islamic Education. Therefore, it takes effort to preserve Islamic Education in the midst of society revolution era 5.0. The systematic of writing in this study include; introduction, research method and discussion.

\section{METHOD}

This research is using literature review method. The data is collected from various documents such as books, journals, articles and information from both print and online media in accordance with the issue of Islamic Education in the era of the society revolution 5.0 which then compiled, sorted, classified, analyzed and discussed.

The data analysis on this library research is using content analysis method, which is deeply discussing the content of the data that has been collected. 


\section{RESULTS AND DISCUSSION}

\subsection{Definition of Islamic Education}

Islamic Education has two meanings, which is education about Islam and education according to Islam. Education about the religion of Islam views Islam as the subject matter in education, whereas education, according to Islam puts Islam as a perspective in Islamic Education (Djazaman, 2009).

So far, Islamic Education has been understood as an education about the religion of Islam, which is only focused on the curriculum, materials and methods on how a teacher delivers to the students. This comprehension is a process of transferring religious values from the elder to the youngster by taking it in without having to create progressive and creative thoughts by the students (Syam, 2019).

Generally, Islamic Education aims to increase the students' faith, understanding, appreciation and experiences about the religion of Islam, so that they become Muslims whom faithful and devoted to Allah SWT and have the noble character in their personal, social, national and state life.

Islamic Education has five purposes, as stated by Athiyah al-Abrasyi. Firstly, establishing noble morals. Secondly, as a provision in life in the world and hereafter. Thirdly, generating enthusiasm for learning and curiosity. Fourthly, professional students. Fifthly, work readiness and maintenance of beneficial aspects (Zuhairini, 2015).

\subsection{The Era of Society Revolution 5.0}

The era of society revolution 5.0 can be interpreted as a concept where society is centred on humans (humancentred) and technology-based. This society 5.0 concept occurs as the development of the industrial revolution 4.0 as an effort to synergize humans (human-centred) and technology (technology-based) (Umro, 2020).

Artificial intelligence which exists on technology is an effort to help humans create opportunities from every life aspects. Humans are helped by data from the internet which then could be processed as material to create opportunities (Santoso, 2020).

The artificial intelligence in society era 5.0 prioritizes the human aspect. This aspect will be the one which change millions of data from the internet for life towards a new order. The balance between economic and social problems needs to be emphasized in the era of society 5.0 to help humans towards meaningful lives (Pradipta, 2020).

The era of society 5.0 is to create a society that can take advantage of technology and enjoy life. The concept of society 5.0 is an attempt to resolve human problems of the industrial revolution 4.0, which has begun to degrade the role of humans.

\subsection{Existence of Islamic Education}

In 2016 McKinsey stated in his research that there would be more than 50 million jobs lost within five years. This is a message to each and every individual to keep on growing, to be mentally prepared and strengthen the ability to compete in the midst of the times. The steps that must be prepared are the morals within yourselves (behaviour and attitude), increase your competency and cultivating literacy. These steps can be achieved by long-life education and exchanging experiences with anyone (Suwardana, 2017).
Based on the statement above, it is necessary to make a change in Islamic Education, namely by adjusting to the era of society 5.0, with the intention of adapting to future needs. In his speech, Muhadjir Effendy stated that it is necessary to increase human resources and learning technology, so that education can adapt to the times (Saputro, 2020).

In the midst of ever-changing time, Islamic Education should be able to compete in it. But there are some problems that exist in Islamic Education; first, inadequate human resources; second, many teachers are in their elderly age phase (Candra, 2018); third, incomplete infrastructures (Sinaga, 2017); fourth, Islamic Education teaching methodology runs in a conventional-traditional manner (Wardi, 2013).

Apart from the four problems described above, there are four things that brought criticism to Islamic Education. First, the development of science and technology is not accompanied by the development of Islamic Education; it could be stated that the response of Islamic Education to science and technology's development is slow. Second, there is a grouping of knowledge, separating religious and general science. Third, there are differences of opinions among education policymakers (Priatmoko, 2018).

In welcoming the era of society 5.0 , there must be a way out so that Islamic Education can still be accepted in the midst of the times. If not, Islamic Education will have difficulty adjusting to the times (Haris, 2019). Therefore, there is a need for change and renewal in all aspects of Islamic Education. There are at least three steps that Islamic Education must take in this era of society 5.0, as Rhenald Kasali stated: a disruptive mindset, self-driving and reshaping or creating (Kasali, 2018).

Adjustment of the mindset (disruptive mindset), is namely determining the setting before thinking or acting. In today's world, which everything is fast-paced and information can be accessed at any time is a primary need for everyone. Educational actors need to form a mindset, especially in Islamic Education, so as not to appear that Islamic Education is always left behind (Haris, 2019). Today's society demands the presence of something new and in accordance with the reality, this is also stimulating innovation and creativity in learning.

Self-driving person means that he/she is like a good driver so they can control all changes, no longer as a passenger. Good drivers are created from human resources who can manage themselves, adapt to every situation, be prepared for bad outcomes, and are required to be creative, effective, and efficient at work (Purnomo, 2020). The ability as a good driver is what Islamic Education needed.

Reshape or create, means that to receive and then process it to be formed or changed into something new. "About something old, if it is good, then keep it up, and accept new ones to be processed for the better", is the popular genealogy among the people. The existence of a modification process in Islamic Education in society era 5.0 is expected to maintain its existence so as not to be left behind with the times (Priatmoko, 2018).

Apart from the three things that have been mentioned above, to maintain its existence in the era of society revolution 5.0, there are other things that can be done. So that Islamic Education can still survive in the midst of the times, especially in facing the era of society 5.0 (Syakur, 2016). First, we must be able to take advantage of technol- 
ogy which means that using technology to improve quality, not as an obstacle to creativity. Second, science, technology and imtaq used to increase human resources spiritually, morally and intellectually. Third, changes to the system towards modernization, starting from mindset to evaluation. Islamic Education must have a sense of development so that it can survive in the middle of this 5.0 society era.

\section{CONCLUSION}

Generally, Islamic Education aims to increase the students' faith, understanding, appreciation and experiences about the religion of Islam, so that they become Muslims whom faithful and devoted to Allah SWT and have noble character in their personal, social, national and state life.

The era of society revolution 5.0 could be interpreted as a concept where humans are the center of the society (human-centred) and technology-based. This new era of society aims for humans to lead meaningful lives. The concept of society 5.0 is an attempt to resolve human problems of the industrial revolution 4.0 which has begun to degrade humans' role.

Islamic Education should be able to compete in this ever-changing time. The steps that must be taken by Islamic Education in the era of society 5.0, as stated by Rhenald Kasali, are disruptive mindset, self-driving and reshape or create. Furthermore, Islamic Education should be able to utilize technological tools to increase the quality of its education. The quality of science, technology and imtaq should also improve human resources in Islamic Education spiritually, morally and intellectually.

\section{REFERENCES}

Astawa, I.N.T. (2016). Teori-teori Dalam Pendidikan Modern. Jurnal Penjamin Mutu, 2(1), 67-72.

Candra, B.Y. (2018). Problematika Pendidikan Islam. Jurnal Istighna, 1(1), 134-153.

Djazaman, M. (2009). Konsep Pendidikan Islam, Jurnal Ilmu Pendidikan Islam, 1, 90-101.

Haris, M. (2018). Manajemen Lembaga Pendidikan Islam Dalam Menghadapi Revolusi Industri 4.0. Jurnal manajemen Pendidikan, 1(1), 45-57.

Ifadah, L. \& Utomo, S.T. (2019). Strategi Pembelajaran Pendidikan Agama Islam Dalam Menghadapi Tantangan Era Revolusi Industri 4.0. Jurnal al-Ghazali : Jurnal Kajian Pendidikan Islam dan Studi Islam, 2(2), 51-62.
Kasali, R. (2018). Disruption. Jakarta: Gramedia. Nastiti, F.E. \& Abdu, A.R.N. (2020). Kesiapan Pendidikan Indonesia Menghadapai Era Society 5.0, Jurnal Kajian Teknologi Pendidikan, 5(1), 61-66. $\begin{array}{cccr}\text { Pradipta, } & \text { R.R. } & (2020) . & \text { Masyarakat } \\ \text { Baru } & 5.0 & \text { [Online], } & \text { Accessed from } \\ \text { https://www.qureta.com/post/masyarakat-baru- }\end{array}$ 5-0.

Priatmoko, S. (2018). Memperkuat Eksistensi Pendidikan Islam di Era 4.0, TA'LIM : Jurnal Studi Pendidikan Islam, 1(2), 1-19.

Purnomo, S. (2020). Reformulasi Kepemimpinan Pendidikan Islam Di Era Revolusi Industri 4.0. Jurnal Insania, 25(1), 54-64.

Riyadi, M. (2018). Memperkuat Eksistensi Pendidikan Agama Islam Di Tengah Kemajuan Ilmu Pengetahuan. Risalah : Jurnal Pendidikan dan Studi Islam, 4(2), 149-167.

Santoso, K.A. (2020). Pendidikan untuk menyambut Masyarakat Society 5.0 [Online], Accesed from https://www.alinea.id/kolom/pendidikan-untukmenyambut-masyarakat-5-0-b1XcI9ijL.

Saputro, F.A. (2020). Mendikbud Ungkap Cara Hadapi Revolusi 4.0 di Pendidikan [Online], accessed from https://www.republika.co.id/berita/pendidikan/education/18/05 mendikbud-ugkap-carahadapi-revolusi-40-dipendidikan.

Sinaga, S. (2017). Problematika Pendidikan Agama Islam Di Sekolah dan Solusinya. Jurnal Waraqat, 2(1), 175-188.

Suwardana, H. (2017). Revolusi Industri 4.0 Berbasis Revolusi Mental. Jurnal Jati UNIK, 1(2), 102-110.

Syakur, A. (2016). Revitalisasi Teknologi Pendidikan Islam. Jurnal Tadris, 11(2). 170-187.

Syam, A.R. (2015). Guru dan Pengembangan Kurikulum Pendidikan Agama Islam di Era Revolusi Industri 4.0, Jurnal Tadris, 14(1), 1-18.

Umro, J. (2020). Tantangan Guru Pendidikan Agama Islam Dalam Menghadapi Era Society 5.0. Jurnal al-Makrifat, 5(1), 79-95. Wardi, M. (2013). Problematika Pendidikan Islam dan Solusi Alternatifnya. Jurnal Tadris, 8(1), 54-70.

Zuhairini. (2015.) Filsafat Agama Islam. Jakarta : Bumi Aksara. 